\title{
Killing for conservation: the need for alternatives to lethal sampling of apex predatory sharks
}

\author{
Neil Hammerschlag ${ }^{1,2,3, *}$, James Sulikowski ${ }^{4}$ \\ ${ }^{1}$ Rosenstiel School of Marine and Atmospheric Science, University of Miami, 4600 Rickenbacker Causeway, Miami, \\ Florida 33149, USA \\ ${ }^{2}$ Leonard and Jayne Abess Center for Ecosystem Science and Policy, University of Miami, PO Box 248203, Coral Gables, \\ Florida 33124, USA \\ ${ }^{3}$ RJ Dunlap Marine Conservation Program, University of Miami, 4600 Rickenbacker Causeway, Miami, Florida 33149, USA \\ ${ }^{4}$ University of New England, Marine Sciences Department, Marine Science Center, 11 Hills Beach Road, Biddeford, \\ Maine 04005, USA
}

\begin{abstract}
Top oceanic predators, especially large predatory sharks (TOPS), appear to be experiencing varying degrees of population declines. Life history data (e.g. diet, reproductive status, age and growth, mortality) are critical for developing effective conservation strategies for TOPS. Presently, lethal sampling remains the most effective and accurate means of gathering these data. To meet such challenges, many scientists have utilized specimens obtained from recreational and commercial fisheries, but have needed to supplement those data with fishery-independent sampling. However, there is growing public and scientific debate as to whether lethal sampling of TOPS is justified for obtaining conservation data. Here we describe the development and use of non-lethal alternatives for collecting data on (1) trophodynamics; (2) maturity state and fecundity; and (3) growth and mortality rates necessary to enact conservation measures for threatened or even data-deficient TOPS.
\end{abstract}

KEY WORDS: Conservation - Shark - Scientific sampling · Lethal sampling • Population status • Life history $\cdot$ Fisheries

Resale or republication not permitted without written consent of the publisher

\section{INTRODUCTION}

Through growing public awareness of the threats facing wildlife and the widespread exposure of 'green' issues, the public, press, scientists, and politicians alike are 'jumping on the conservation bandwagon' and arguing for protection of many threatened species. There are numerous lines of evidence that top oceanic predators, especially large predatory sharks (hereafter TOPS sensu Jacques 2010), are experiencing varying degrees of population decline (Pauly et al. 1998, Baum et al. 2003, Myers \& Worm 2003, Hampton et al. 2005, Sibert et al. 2006, Myers et al. 2007, Dulvy et al. 2008). Subsequently, there is mounting debate as to whether lethal sampling of TOPS is justified for obtaining scientific data. Recently, this controversial issue was objectively tackled by
Heupel \& Simpfendorfer (2010). In their paper, the authors concluded that with respect to sharks:

...Although lethal sampling comes at a cost to a population, especially for threatened species, the conservation benefits from well-designed studies provide essential data that cannot be collected currently in any other way... (p. 1212)

Life history data (diet, reproductive status, age and growth, mortality) are critical for developing effective conservation strategies for sharks, and Heupel \& Simpfendorfer (2010) argued that lethal sampling presently remains the most effective and accurate means of gathering these data. To meet such challenges, many scientists have relied on fishery-derived specimens, but have needed to supplement those data with fishery-independent sampling (e.g. Piercy et al. 2010). In many terrestrial predators, marine mammals, and even some 
fishes, accepted non-lethal alternatives exist for obtaining life history and demographic data; however, at present, comparable alternatives are not yet widely used to study TOPS. Ethical, political, and emotional issues aside, lethal sampling does provide a variety of valuable biological and ecological data that cannot be otherwise achieved (Heupel \& Simpfendorfer 2010). However, if the goal is conservation, we need to employ multi-disciplinary approaches to develop widely accepted alternatives to traditional lethal techniques for generating data necessary to enact conservation measures for threatened or even data-deficient TOPS.

Do researchers who study large terrestrial carnivores (e.g. lions Panthera leo, bald eagles Haliaeetus leucocephalus, jaguars $P$. onca) even consider lethal sampling as a viable option for obtaining demographic or life history data for enacting conservation measures? We failed to find any evidence that this was the case (e.g. Brown 1976, Lehmann et al. 2008, Ferreira \& Funston 2010). Do the inherent difficulties imposed by working in the ocean make lethal sampling of TOPS a more necessary option for obtaining conservation data? Working in the marine environment certainly does present obstacles not encountered in terrestrial systems; however, studies of marine mammals and even fishes have found non-lethal alternatives for collecting life history and demographic information (Weber \& Innis 2007). Below we describe the use and development of potential non-lethal alternatives for collecting data on (1) trophodynamics; (2) maturity state and fecundity; and (3) growth and mortality rates.

\section{TROPHODYNAMICS}

Studies of diets and feeding patterns can contribute to an understanding of ecological interactions and community structure (e.g. Winemiller 1989, Krebs 1998, Hammerschlag et al. 2010). Such data are useful for developing trophic models as tools for understanding multi-species fisheries (Christensen \& Pauly 1992, Walters et al. 1997). These data are traditionally obtained through gut content analysis. Several studies have used non-lethal stomach eversion or gastric lavage techniques (e.g. Cortés \& Gruber 1990, Barnett et al. 2010). Stomach contents can also be obtained from TOPS already harvested in commercial and recreational fisheries (e.g. Stillwell \& Kohler 1982, Bowman et al. 2000, Maia et al. 2006). However, recreational and commercial fisheries sometimes only sample a relatively narrow portion of the length-age distribution of a population; thus many studies have relied on supplementing these data with fishery-independent surveys to obtain samples needed to investigate ontogenetic changes in actual diet.
Regardless of technique employed, gut content analyses usually fail to identify prey items to species level due to differential digestive rates (Bowen 1996). The use of a complementary measure, particularly stable isotope (SI) analysis, provides insights on an individual's long-term diet, ontogenetic or seasonal diet shifts, as well as information on trophic position (Araújo \& Gonzaga 2007). For SI analyses, only small samples of muscle, fin, or blood are needed, and these tissues can be easily, quickly and non-invasively obtained in the field (Gallagher et al. 2010). Indeed, several recent studies have incorporated SI to examine trophodynamics of TOPS (MacNeil et al. 2005, Estrada et al. 2006, Logan \& Lutcavage 2010). However, SI does not provide information on the identity of taxa actually being eaten. Thus, when designing a study on feeding habits of TOPS, investigators should first consider whether SI could be used to address the questions being investigated before adopting a lethal method.

Another promising non-lethal technique is employing stomach flushing (gastric lavage) in combination with deoxyribonucleic acid (DNA) analysis of gut contents. Recently, Barnett et al. (2010) tested this method on subadult and adult broadnose sevengill sharks Notorynchus cepedianus up to $\sim 3 \mathrm{~m}$ in total length. By undertaking molecular analysis of unidentifiable prey, the number of species-specific identifications of prey was double that which could be obtained without use of DNA techniques. Further, after releasing sampled sharks equipped with acoustic transmitters, subsequent tracking demonstrated high survivorship postfishing and stomach flushing (Barnett et al. 2010).

\section{MATURITY STATE AND FECUNDITY}

Data on maturity state, gestation period, and fecundity are important for generating population models used to estimate sustainable harvest levels. For TOPS, these parameters have traditionally been derived through sacrificing of specimens. Such data have been obtained from dead specimens harvested in commercial and recreational fisheries (Whitney \& Crow 2007, Harry et al. 2010). Data collection could further be maximized by increased cooperation and coordination between fishers and scientists. However, determination of reproductive timing and maturity requires sampling of all developmental stages and all months for both sexes. Commercial and recreational fishery catches often reflect a small portion of the year (due to regulations or migratory patterns), only include a small span of the length and age distributions, and are often sex-biased. Further, sacrificing animals in order to obtain reproductive data can be problematic, especially for species that 
have been classified as Endangered or Threatened (e.g. Sulikowski et al. in press). Thus, unless non-lethal sampling techniques are developed or those currently in use are fine-tuned, information regarding reproductive biology for prohibited species will be difficult or impossible to obtain.

Despite these difficulties, a wide range of potential solutions do exist. Intrauterine endoscopy has shown promise as a non-lethal technique as it can directly visualize the progress of gestation (Carrier et al. 2003). However, despite its non-lethal nature, use of this technique has the potential to produce detrimental side effects, including spontaneous abortion and accelerated gestation (Carrier et al. 2003). In recent years, circulating concentrations of plasma steroid hormones, such as 17- $\beta$-estradiol $\left(\mathrm{E}_{2}\right)$, progesterone $\left(\mathrm{P}_{4}\right)$, and testosterone $(\mathrm{T})$, have been used in combination with an examination of gross morphological changes to evaluate events associated with reproductive cycles and sexual maturity in a number of elasmobranchs (Manire et al. 1995, Heupel et al. 1999, Carrier et al. 2003, Sulikowski et al. 2006, 2007, Awruch et al. 2008, Hoffmayer et al. 2010, Sulikowski et al. in press). While the results from these studies indicate that morphological changes in reproductive tracts and gonadal steroid hormone biosynthesis are intimately linked in elasmobranch reproduction, this technique requires further validation across all reproductive modes. Another methodology that has the potential to be used as a non-lethal technique is ultrasound imaging, especially since this technology has become small and portable (e.g. 3.0-7.5 EC 7.5 MHz probes, Interson Corporation).

While studies of TOPS using ultrasound have been limited, this technique has successfully been used to visually monitor the reproductive status of broadnose sevengill sharks (Daly et al. 2007) and maturity in the thornback ray Raja clavata and small-spotted catshark Scyliorhinus canicula (Whittamore et al. 2010). Although ultrasound studies have experienced difficulties in distinguishing between reproductive features within an elasmobranch, coupling the use of ultrasound with steroid hormone analysis can provide a means to biochemically and visually assess reproductive biology, leading to a more accurate, and truly noninvasive, determination of this life history parameter.

\section{AGE, GROWTH, AND MORTALITY RATES}

Age information forms the basis for the calculations of growth rate, mortality rate, and productivity, making it one of the most important variables for estimating a population's status and assessing the risks associated with its exploitation (Ricker 1975, Cortés 1998, Cailliet
\& Goldman 2004, Goldman 2005). The ability to perform age determinations based on the examination of hard anatomical parts is of fundamental importance in fisheries research (Goldman 2005). In most chondrichthyans, enumeration of growth zones deposited in vertebral centra provides the most reliable method of estimating age-at-length (Cailliet \& Goldman 2004, Goldman 2005). This entails post-mortem extraction of vertebrae which can be obtained from 'already-dead' animals, but usually requires supplementing with fishery-independent surveys. Tag and release experiments can also be designed in combination with postmortem vertebrae studies to examine growth rates and age-validation in TOPS (Kohler \& Turner 2001). This has been achieved, for example, in lemon sharks Negaprion brevirostris (Gruber \& Stout 1983), tiger sharks Geleocerdo cuvier (Natanson et al. 1999), blue sharks Prionace glauca (Skomal 1990), and sandbar sharks Carcharhinus plumbeus (Casey \& Natanson 1992). The use of external hard parts, such as spines and thorns, to non-lethally age chondrichthyans has generally yielded less than satisfactory results and is typically associated with high inter-reader bias and low repeatability (e.g. Davis et al. 2007, Barnett et al. 2009). In addition, the general usefulness of these structures appears to be species-specific and limited to chondrichthyans possessing those structures (e.g. Gallagher \& Nolan 1999, Irvine et al. 2006).

More recently, non-invasive estimates of growth and mortality rates of fishes have been generated by analyzing nucleic acid levels and RNA:DNA ratios from tissue biopsies (Buckley et al. 1999, Vinagre et al. 2008). To date, these methods have been mainly used to estimate condition-based growth rates over short time scales in small fishes. However, further research and development is needed to determine if and how RNA:DNA ratios from tissue biopsies could be applied to sharks for estimating growth rates over many years, as required for demographic modeling.

\section{CONCLUSION}

In the case of TOPS which are highly protected, lethal sampling is not an option. As such, scientists have generated innovative non-lethal alternatives for obtaining data on trophodynamics, age-growth, maturity, and reproductive status. This is best exemplified in the white shark Carcharodon carcharias, which is designated as Vulnerable to Extinction by The International Union for Conservation of Nature (IUCN; Fergusson et al. 2005), listed on Appendix II of the Convention on International Trade in Endangered Species (CITES), and fully protected in South Africa, Namibia, the USA, Australia, Israel, Italy, and Malta (Fergusson et al. 2005). 
For example, white shark diet and feeding habits have been determined from gut content analysis of specimens obtained from fisheries (Cliff et al. 1989, Bruce 1992, Cortés 1999, Hussey et al. in press, Smale \& Cliff in press). Sulikowski et al. (in press) recently developed non-lethal techniques to assess the reproductive biology of white sharks. Moreover, electronic tagging (Domeier \& Nasby-Lucas 2008, Weng et al. 2007, Jorgensen et al. 2010), mark-recapture (Anderson et al. 2011), photo identification (Domeier \& Nasby-Lucas 2007, Chapple et al. 2011), and application of molecular genetics (Gubili et al. 2009, Jorgensen et al. 2010) have been used to determine population size and structure of white sharks in a variety of locations.

In his book 'Why big fierce animals are rare: an ecologist's perspective,' Colinvaux (1978) elegantly described how the second law of thermodynamics restricts the abundance and size of apex predators. He wrote:

...Great white sharks or killer whales in the sea, and lions and tigers on the land...are very thinly spread. One may swim many lifetimes in the world oceans without encountering a great white shark... (p. 27)

Even nearly a century ago, long before overfishing, Elton (1927) pointed out that large carnivores were rare. Given the threatened status of many TOPS, there is a growing need to develop feasible alternatives to lethal sampling. We recognize that this will not happen overnight; but as scientists, we need to become creative, collaborate, and challenge ourselves to do so, because this is the direction we need to be moving in, if conservation is our goal.

Acknowledgements. Thank you to M. O'Malley, J. Abernethy, B. Davis, A. Gallagher, E. P. S. Webber, C. M. Hammerschlag, and J. Serafy for encouragement and support. Special thanks to S. J. Cooke and the anonymous reviewers, whose criticisms and suggestions helped significantly strengthen this paper. Funding was provided by Shark Foundation, Batchelor Foundation Inc., Guy Harvey Ocean Foundation, RJ Dunlap Marine Conservation Program, and Wells Fargo.

\section{LITERATURE CITED}

Anderson SD, Chapple TK, Jorgensen SJ, Klimley AP, Block BA (2011) Long-term individual identification and site fidelity of white sharks, Carcharodon carcharias, of California using dorsal fins. Mar Biol. 158:1233-1237

Araújo MS, Gonzaga MO (2007) Individual specialization in the hunting wasp Trypoxylon (Trypargilum) albonigrum (Hymenoptera, Crabronidae). Behav Ecol Sociobiol 61: 1855-1863

Awruch CA, Pankhurst NW, Fusher SD, Stevens JD (2008) Endocrine and morphological correlates of reproduction in the draughtboard shark Cephaloscyllium laticeps (Elasmobranchii: Scyliorhinidae). J Exp Zool 309A:184-197

Barnett LAK, Ebert DA, Cailliet GM (2009) Assessment of the dorsal fin spine for chimaeroid (Holocephali: Chimaeriformes) age estimation. J Fish Biol 75:1258-1270
Barnett A, Redd KS, Frusher SD, Stevens JD, Semmens JM (2010) Non-lethal method to obtain stomach samples from a large marine predator and the use of DNA analysis to improve dietary information. J Exp Mar Biol Ecol 393: 188-192

Baum JK, Myers RA, Kehler DG, Worm B, Harley SJ, Doherty PA (2003) Collapse and conservation of shark populations in the Northwest Atlantic. Science 299:389-392

Bowen S (1996) Quantitative description of the diet. In: Murphy BR, Willis DW (eds) Fisheries techniques, 2nd edn. American Fisheries Society, Bethesda, MD, p 513-532

Bowman R, Stillwell C, Michaels W, Grosslein M (2000) Food of Northwest Atlantic fishes and two common species of squid. Tech Rep NMFS-NE-155. National Marine Fisheries Service, Mashpee, MA

Brown L (1976) Birds of prey: their biology and ecology. Hamlyn Publishing, London

Bruce BD (1992) Preliminary observations on the biology of the white shark, Carcharodon carcharias, in South Australian waters. Aust J Mar Freshw Res 43:1-11

> Buckley LJ, Caldarone E, Ong TL (1999) RNA-DNA ratio and other nucleic acid-based indicators for growth and condition of marine fishes. Hydrobiologia 401:265-277

Cailliet GM, Goldman KJ (2004) Age determination and validation in chondrichthyan fishes. In: Carrier J, Musick JA, Heithaus M (eds) The biology of sharks and their relatives. CRC Press, Boca Raton, FL, p 399-447

Carrier J, Murru F, Walsh M, Pratt HL (2003) Assessing reproductive potential and gestation in nurse sharks (Ginglymostoma cirratum) using ultrasonography and endoscopy: an example of bridging the gap between field research and captive studies. Zoo Biol 22:179-187

Casey JG, Natanson LJ (1992) Revised estimates of age and growth of the sandbar shark (Carcharhinus plumbeus) from the western North Atlantic. Can J Fish Aquat Sci 49: 1474-1477

Chapple TK, Jorgensen SJ, Anderson SA, Kanive PE, Klimley AP, Botsford LW, Block BA (2011) A first estimate of white shark, Carcharodon carcharias, abundance off central California. Biol Lett. doi:10.1098/rsbl.2011.0124

Christensen V, Pauly D (1992) ECOPATH-II: a software for balancing steady-state ecosystem models and calculating network characteristics. Ecol Model 61:169-185

Cliff G, Dudley SFJ, Davis B (1989) Sharks caught in the protective gillnets off Natal, South Africa. 2. The great white shark Carcharodon carcharias (Linnaeus). S Afr J Mar Sci 8:131-144

Colinvaux PA (1978) Why big fierce animals are rare: an ecologist's perspective. Princeton University Press, Princeton, NJ

Cortés E (1998) Demographic analysis as an aid in shark stock assessment and management. Fish Res 39:199-208

Cortés E (1999) Standardized diet compositions and trophic levels of sharks. ICES J Mar Sci 56:707-717

> Cortés E, Gruber SH (1990) Diet, feeding habits, and estimates of daily ration of young lemon sharks, Negaprion brevirostris (Poey). Copeia 1990:204-218

Daly J, Gunn I, Kirby N, Jones R, Galloway D (2007) Ultrasound examination and behavior scoring of captive broadnose sevengill sharks, Notorynchus cepedianus (Peron, 1807). Zoo Biol 26:383-395

Davis CD, Cailliet GM, Ebert DA (2007) Age and growth of the roughtail skate Bathyraja trachura (Gilbert, 1892) from the eastern North Pacific. Environ Biol Fishes 80: 325-326

> Domeier ML, Nasby-Lucas N (2007) Annual re-sightings of photographically identified white sharks (Carcharodon 
carcharias) at an eastern Pacific aggregation site (Guadalupe Island, Mexico). Mar Biol 150:977-984

> Domeier ML, Nasby-Lucas N (2008) Migration patterns of white sharks Carcharodon carcharias tagged at Guadalupe Island, Mexico, and identification of an eastern Pacific shared offshore foraging area. Mar Ecol Prog Ser 370:221-237

Dulvy NK, Baum JK, Clarke S, Compagno LJV and others (2008) You can swim but you can't hide: the global status and conservation of oceanic pelagic sharks and rays. Aquat Conserv 18:459-482

Elton C (1927) Animal ecology. Macmillan, New York, NY

Estrada JA, Rice AN, Natanson LJ, Skomal GB (2006) Use of isotopic analysis of vertebrae in reconstructing ontogenetic feeding ecology in white sharks. Ecology 87:829-834

Fergusson I, Compagno LVJ, Marks M (2005) Carcharodon carcharias. In: IUCN Red List of Threatened Species. Version 2010.4. Available at www.iucnredlist.org (accessed on 21 April 2011)

Ferreira S, Funston PJ (2010) Age assignment to individual African lions. S Afr J Wildl Res 40:1-9

Gallagher M, Nolan CP (1999) A novel method for the estimation of age and growth in rajids using caudal thorns. Can J Fish Aquat Sci 56:1590-1599

Gallagher AJ, Frick LH, Bushnell PG, Brill RW, Mandelman JW (2010) Blood gas, oxygen saturation, $\mathrm{pH}$, and lactate values in elasmobranch blood measured with a commercially available portable clinical analyzer and standard laboratory instruments. J Aquat Anim Health 22:229-234

Goldman KJ (2005) Age and growth of elasmobranch fishes. In: Musick JA, Bonfil R (eds) Management techniques for elasmobranch fisheries. FAO Fish Tech Pap No 474. FAO, Rome, p 97-132

Gruber SH, Stout RG (1983) Biological materials for the study of age and growth in a tropical marine elasmobranch, the lemon shark, Negaprion brevirostris (Poey). In: Prince ED, Pulos LM (eds) Proceedings of the international workshop on age determination of oceanic pelagic fishes: tunas, billfishes, and sharks. NOAA Tech Rep NMFS 8, Miami, FL, p 193-205

Gubili C, Johnson R, Gennari E, Oosthuizen W and others (2009) Concordance of genetic and fin photo identification in the great white shark, Carcharodon carcharias, off Mossel Bay, South Africa. Mar Biol 156:2199-2207

Hammerschlag N, Ovando D, Serafy JE (2010) Seasonal diet and feeding habits of juvenile fishes foraging along a subtropical marine ecotone. Aquat Biol 9:279-290

> Hampton J, Sibert JR, Kleiber P, Maunder MN, Harley SJ (2005) Decline of Pacific tuna populations exaggerated? Nature 434:E1-E2

Harry AV, Simpfendorfer CA, Tobin AJ (2010) Improving age, growth and maturity estimates for aseasonally reproducing chondrichthyans. Fish Res 106:393-403

> Heupel MR, Simpfendorfer CA (2010) Science or slaughter: need for lethal sampling of sharks. Conserv Biol 24:1212-1218

Heupel MR, Whittier JM, Bennett MB (1999) Plasma steroid hormone profiles and reproductive biology of the epaulette shark Hemiscyllium ocellatum. J Exp Zool (Endocrinol Suppl) 284:586-594

Hoffmayer ER, Sulikowski JA, Hendon JM, Parsons GR (2010) Plasma steroid concentrations of adult male Atlantic sharpnose sharks, Rhizoprionodon terraenovae, in the northern Gulf of Mexico, with notes on potential long term shifts in reproductive timing. Environ Biol Fishes 88:1-7

Hussey NE, McCann HM, Cliff G, Dudley SFJ, Wintner SP, Fisk AT (in press) Size-based analysis of diet and trophic position of the white shark (Carcharodon carcharias) in
South African waters. In: Domeier ML (ed) Global perspectives on the biology and life history of the great white shark. CRC Press, Boca Raton, FL

Irvine SB, Stevens LD, Laurenson LJB (2006) Surface bands on deepwater squalid dorsal-fin spines: an alternative method for ageing Centroselachus crepidater. Can J Fish Aquat Sci 63:617-627

Jacques PJ (2010) The social oceanography of top oceanic predators and the decline of sharks: a call for a new field. Prog Oceanogr 86:192-203

> Jorgensen SJ, Reeb CA, Chapple TK, Anderson S and others (2010) Philopatry and migration of Pacific white sharks. Proc Biol Sci 277:679-688

- Kohler NE, Turner PA (2001) Shark tagging: a review of conventional methods and studies. Environ Biol Fishes 60: 191-223

Krebs CJ (1998) Ecological methodology. Addison-Wesley Educational Publishers, Menlo Park, CA

Lehmann MB, Funston PJ, Owen CR, Slotow R (2008) Reproductive biology of a pride of lions on Karongwe Game Reserve, South Africa. Afr Zool 43:230-236

> Logan JM, Lutcavage ME (2010) Stable isotope dynamics in elasmobranch fishes. Hydrobiologia 644:231-244

MacNeil MA, Skomal GB, Fisk AT (2005) Stable isotopes from multiple tissues reveal diet switching in sharks. Mar Ecol Prog Ser 302:199-206

> Maia A, Queiroz N, Correia JP, Cabral H (2006) Food habits of the shortfin mako, Isurus oxyrinchus off the southwest coast of Portugal. Environ Biol Fishes 77:157-167

> Manire CA, Rasmussen LEL, Hess DL, Hueter RE (1995) Serum steroid hormones and the reproductive cycle of the female bonnethead shark, Sphyrna tiburo. Gen Comp Endocrinol 97:366-376

Myers RA, Worm B (2003) Rapid worldwide depletion of predatory fish communities. Nature 423:280-283

> Myers RA, Baum JK, Shepherd TD, Powers SP, Peterson CH (2007) Cascading effects of the loss of apex predatory sharks from a coastal ocean. Science 315:1846-1850

Natanson LJ, Casey JG, Kohler NE, Colket T (1999) Growth of the tiger shark (Galeocerdo cuvier) in the western North Atlantic, based on tag returns and length-frequencies; and a note on the effects of tagging. Fish Bull 97:944-953

Pauly D, Christensen V, Dalsgaard J, Froese R, Torres F (1998) Fishing down marine food webs. Science 279: 860-863

> Piercy AN, Carlson JK, Passerotti MS (2010) Age and growth of the great hammerhead shark, Sphyrna mokarran, in the north-western Atlantic Ocean and Gulf of Mexico. Mar Freshw Res 61:992-998

Ricker WE (1975) Computation and interpretation of biological statistics of fish populations. Bull Fish Res Board Can 191:1-382

Sibert J, Hampton J, Kleiber P, Maunder M (2006) Biomass, size, and trophic status of top predators in the Pacific Ocean. Science 314:1773-1776

Skomal GB (1990) Age and growth of the blue shark Prionace glauca in the North Atlantic. MSc thesis, University of Rhode Island, Kingston, RI

Smale MJ, Cliff G (in press) White sharks and cephalopod prey: indicators of habitat use? In: Domeier ML (ed) Global perspectives on the biology and life history of the great white shark. CRC Press, Boca Raton, FL

> Stillwell C, Kohler N (1982) Food, feeding habits, and estimates of daily ration of the shortfin mako (Isurus oxyrinchus) in the Northwest Atlantic. Can J Fish Aquat Sci 39:407-414 
Sulikowski JA, Kneebone J, Elzey S, Howell WH, Tsang PCW (2006) Using the composite parameters of reproductive morphology, histology and steroid hormones to determine age and size at sexual maturity for the thorny skate, Amblyraja radiata, in the western Gulf of Maine. J Fish Biol 69:1449-1465

Sulikowski JA, Driggers WB, Ingram W, Kneebone J, Ferguson DE, Tsang PCW (2007) Profiling plasma steroid hormones: a non-lethal approach for the study of skate reproductive biology and its potential use in conservation management. Environ Biol Fishes 80:285-292

Sulikowski JA, Domeier ML, Williams LJ (in press) The potential use of non lethal techniques to assess the reproductive biology of the white shark, Carcharodon carcharias. In: Domeier ML (ed) Global perspectives on the biology and life history of the great white shark. CRC Press, Boca Raton, FL

Vinagre C, Fonseca V, Maia A, Amara R, Cabral H (2008) Habitat specific growth rates and condition indices for the sympatric soles Solea solea (Linnaeus, 1758) and Solea senegalensis (Kaup 1858), in the Tagus estuary, Portugal,

Editorial responsibility: Steven Cooke, Ottawa, Ontario, Canada based on otolith daily increments and RNA-DNA ratio. J Appl Ichthyol 24:163-169

Walters C, Christensen V, Pauly D (1997) Structuring dynamic models of exploited ecosystems from trophic mass balance assessments. Rev Fish Biol Fish 7:139-172

Weber ES, Innis C (2007) Piscine patients: basic diagnostics. Compend Contin Educ Vet 29:276-288

Weng KC, Boustany AM, Pyle P, Anderson SD, Brown A, Block BA (2007) Migration and habitat of white sharks (Carcharodon carcharias) in the eastern Pacific Ocean. Mar Biol 152:877-894

Whitney NM, Crow GL (2007) Reproductive biology of the tiger shark (Galeocerdo cuvier) in Hawaii. Mar Biol 151: 63-70

Whittamore JM, Bloomer C, Hanna GM, McCarthy ID (2010) Evaluating ultrasonography as a non-lethal method for the assessment of maturity in oviparous elasmobranchs. Mar Biol 157:2613-2624

Winemiller KO (1989) Ontogenetic diet shifts and resource partitioning among piscivorous fishes in the Venezuelan Llanos. Environ Biol Fishes 26:177-199

Submitted: January 16, 2011; Accepted: May 6, 2011

Proofs received from author(s): June 13, 2011 